\title{
Ocean Drilling rules OK?
}

SIR - An independent review of the Ocean Drilling Program (ODP) that has just been completed contains conclusions that are at variance with those in your recent News article (Nature 379, 193-194; 1996). The review was carried out by a committee made up of 11 eminent scientists from seven countres, including Britain and France. It concluded that "the strong record of achievement by the ODP justifies the continuation and enhancement of the programme", although it also recognized that future success depends on the ability to focus on major scientific objectives.

Throughout its 11-year history, there has been fierce competition from the scientific communities in all member countries, including Britain and France, for drilling time on the drill ship JOIDES Resolution.

In the 1995 planning cycle, more than a hundred active proposals at the beginning of the year were narrowed down to a 'prospectus' of 17 by August. The December planning committee meeting finally selected only 8: these contain the best science for inclusion in operations in 1997.

Of the 19 member countries participating in ODP, I believe that France is the only one consistently criticizing as "grey literature" the volumes that make up Proceedings of the Ocean Drilling Program - Initial Reports and Scientific Results. These represent the basic reference and primary source material for ODP results. The Scientific Results volumes are peer reviewed.

These ODP publications are as widely cited as many international journals. Indeed, French scientists are second only to their US colleagues in the number of such citations. A recent review of publication policy by ODP has endorsed these publications, representing the long-term legacy of the programme, as well as providing for more rapid publication of key results in the conventional 'open literature' - see, for example, the letter in the same issue of Nature (379, 243-246; 1996) by R. J. Behl and J. P. Kennett on their continuing research on core from hole 893 in the Santa Barbara Basin. This important paper relies on the huge compilation of basic data and concepts published in Proceedings of the Ocean Drilling Program - Scientific Results, Vol. 146 (part 2).

The Comité Directeur of ODP-France has recommended that France should remain in ODP until the end of the current phase in 1998, and will consider participation in the next phase if certain French concerns are addressed. Many of these changes are already under way.

The proposed Japanese ocean drilling programme, known as 'OD-21', is intended to be an evolution and enhancement of the present ODP. The strategy clearly laid out in ODP's new Long Range Plan involves operation of both a riser drill ship and the current JOIDES Resolution beyond the year 2003.

As for European support for scientific ocean drilling, ODP officials have just completed preliminary discussions with the Secretariat of the European Science Foundation's European Boards of Marine and Polar Science (see Geotimes 41, 9; 1996) on mechanisms for closer cooperation between ODP and future European initiatives in this area.

Finally, I would like to make one correction and one clarification for the record. Russia is not an active member of the programme. The "Consortium" referred to in the article is the Australia/Canada Consortium for Ocean Drilling. On the matter of funding and contributions, the US National Science Foundation pays $\$ 27.7$ million of ODP's total annual operating budget of $\$ 44.4$ million, or 62 per cent. Each non-US member contributes $\$ 2.95$ million a year towards ODP operations.

\section{David A. Falvey}

(Director, Ocean Drilling Program)

Joint Oceanographic Institutions Inc.,

1755 Massachusetts Avenue, NW,

Suite 800 ,

Washington, DC 20036-2102, USA

\section{The great wave}

SIR - The cover of the 18 January issue of Nature illustrates the woodblock print "The great wave of Kanagwa". The attribution is incorrect. The actual artist is Hokusai, not Eijudo. Eijudo was the editor who printed the print. Hokusai was the master who composed this wonderful image, along with approximately 30,000 others throughout his long life. The print was originally drawn in the late $1820 \mathrm{~s}$, not in 1831 .

\section{Laurence A. Lasky}

Genentech Inc.,

460 Pt San Bruno Blvd,

South San Francisco,

California 94080,

USA

\section{On his own head be it}

SIR - The breach between religion and science widened yet again with the use of the term "cassock" by D. B. Weishampel (Nature 378, 764-765; 1995) to describe the excrescence on the head of Oviraptor. It is not a priestly vestment but a helmet that is intended, that is, a casque.

\section{James Murray}

Department of Biology,

University of Virginia,

Charlottesville,

Virginia 22903, USA
Reasons to write

SIR - The goal of a paper is to spread ideas and knowledge to a wide group of scientists, which seems so obvious that it should be unnecessary to mention. But I am not convinced that all the authors of the articles in Nature and other journals have considered the purpose of their papers.

I think the written communication of ideas in writing has deteriorated lately because of the extensive use of abbreviations and acronyms. Both are used to reduce the length of a text, but at the same time their use leads to a reduction in clarity. For the author and for his close colleagues who use these abbreviations daily, it seems natural and may not cause any problems. But for scientists who hope to broaden their understanding of new ideas in adjacent disciplines, the extensive use of abbreviations can be devastating.

As a referee for various journals, I have noticed that an abbreviation devised for a specific paper is often used only once or a few times. Only a few lines of print have been saved, but the possibility of understanding the paper has been reduced considerably. A limited number of abbreviations for long expressions that recur frequently in a text can reduce the length slightly without jeopardizing comprehension. Authors should, however, be reminded that few readers are probably allowed the luxury of reading a whole paper straight through without frequent and extensive interruptions.

\section{Wibjörn Karlén}

Department of Physical Geography,

Stockholm University,

10691 Stockholm,

Sweden

\section{The great game}

SIR - I was interested to read Daedalus's proposal for the replacement of war by computer simulation (Nature 379, 210; 1996) in an issue that also contained a review of Michael Foot's biography of H. G. Wells (379, 215-216; 1996).

Wells was, of course, one of the founders of modern war-gaming, and in Little Wars proposes the construction of "palaces of war", appointed and upholstered in cork and brimming with lead soldiers, wherein "would-be conquerors and practitioners of real-politik" could fight to their hearts' content, with no little lead widows or orphans to mourn the fallen; "My game is just as good as theirs, and saner by reason of its size," opined Wells, proposing his "homeopathic remedy for war”.

Rob Paul

NERC Institute of Virology

\& Environmental Microbiology, Mansfield Road,

Oxford OX1 3SR, UK 